\title{
How to Understand Chinese Foreign Policy and Role in Northeast Asia
}

\author{
By Wang Yizhou and Li Dongyan (China)
}

\section{How to Define China's Role in Northeast Asia: A Realism View}

Northeast Asia is a region influenced by big powers, and the balance of power is the unique feature of this region. The traditional realism may be the most popular approach to explain and understand the reality of this region. So let's start from this approach. In this region, China, Japan, Russia, and the US are all influential powers, but on one is able to dominate this region by itself, and they check each other. China is regarded a most important power in this region, and also a big threat to the others. According realism approach, how to understand Chinese strength is the key to understand Chinese intention and policy to this region.

According to some criteria, such as the territory, population, nuclear weapons, the increasing economic development, there are many reasons to regard China as a world power. But compared to other world powers, China is still a developing third world country, its power and international influence, both its hard power or soft power, is still limited. How to define China's role in the world is a quite debatable question in the circle of Chinese scholars. More acceptable views include "a country between the Second World and the Third World", "a big country but not a strong power", "a developing power" and "a regional power". ${ }^{1}$ Few hold that China is a world power.

After Chinese reform and opening to the outside world, especially after becoming a WTO member, China is gradually entering the mainstream of world. But Chinese domestic politic system and its ideology are still unacceptable to west countries, and the rising of China is regarded as an increasing of "China threat". Not only some developed countries have a distrust attitude toward China, but also some developing countries, particularly Chinese neighboring countries, are worried about the threat caused by Chinese rising. The pressures and containment policies from outside make China more difficult to play an active role in the world.

\footnotetext{
1. See "China's Status in the World", Global Times, Aug. 25, 2000
} 
There is still a military and economic gap between China and other powers. In hard power, China is obviously behind developed countries such as the US, German, and Japan. In soft power dimension, the United Kingdom and France are much stronger "with a wealth of experience in multilateral diplomacy". They also have "extensive trans-regional ties through the Commonwealth and Francophonie."

The most important factor that constricts Chinese international influence is in domestic dimension, such as Taiwan issue, Tibet issue, and Human rights issue. These issues are main obstacles that constrain China to play an active role in international arena. Internally, these issues draw the government attention to its domestic problems, and weaken its inclination and resources to act as an international player. Internationally, these issues are usually be used to check the development of China by other countries.

The balance of power has existed in this region. The US is not a Northeast Asian country geographically, but it is the only global superpower today. Northeast Asia is one crucial part of its national security and global strategy. To maintain the leadership of the United States in the world, and prevent the rising of a regional or global power to threat the US interests, is important one of American strategy goals, only America is able to have such a great global goal to keep its leading role in the world. Obviously the US has important interests in this region, and at least, it needs a regional balance that favors it, if not a domination position. Today in Asia, the United States has better relations with Russia, China, Japan, South Korea, and of course Taiwan, than theses their relations with one another. "Moreover, the lesser states like Thailand or Vietnam would rather huddle under the American umbrella than be exposed to the larger Pacific powers", "All of Asia counts on the US security guarantee to keep Japan from concerting its vast richesse into military prowess. Both China and Russia look to the United State as an implicit ally against each other...." These are typical realism views of describing the balance of power in Asia.

China doesn't have strength to challenge the other powers and establish its dominance this region constrained by the balance of power. From traditional realism view, Chinese policy toward this region is in base of the self-estimation of its strength and the balance of power. Today's Chinese leaders are inclined

${ }^{2}$. Edited by Paul Taylor and A.J.R.Groom, The United Nations at the Millennium, Continuum, London and New York, 2000, p. 299

${ }^{3}$ See Josef Joffe, "'Bismarck or Britain' Toward an American Grand Strategy after Bipolarity”, International Security, Vol.19, No.4 (Spring 1995), pp. 94-117 
to recognize the balance of power in this region, and would not like to challenge the other powers.

First, China has neither strength nor intention to challenge the US existence in this region, recognizing American role as a balancer and doesn't oppose against the bilateral security agreements between other East Asian countries with the US (such as the treaty between the US and Japan, Australia, New Zealand, Thailand, and South Korea) if these agreements do not turn to target at China or include the Taiwan.

China also recognizes Russia's influence in this region, and supports this Eurasian state play a role in this region. China believes that Russia should be an important participator in the process of Asian economical, political, and security cooperation. With the same reason, China does not deny Japanese role in this region as an economical and political power, with the precondition of its deeply self-examination of the history. Germany is playing a very important role in the process of European integration, and this can be the example of Japan.

China is an important regional power, especially in Northeast Asia. But the goal of Chinese Northeast Asia policy is not to make China a dominant power in this region, but one normal power in this region. The balance of power in this region can be an explanation for Chinese intention.

We started with realism approach to explain Chinese position and intention in this region. In traditional views, we like to describe Northeast Asia in this way: the development of China is a threat to other powers, the improvement of Russia-China relations poses a threat to the US interests, and the strengthening of Russia-Japan relations is for check of China, also, a united Korea will be a threat of Japan and China.

We don't deny the balance of power in this region. But realism can't explain all behaviors of a state, and it should not be the only approach to discuss Northeast Asian issues. You can't just use the "zero-sum games" or "balance of power" to describe what has happened and will happen in the world or in this region. Russia turned from the main rivalry to a partner of the US not because of the change of power, but the change of conception. China has changed its worldview, and wanted to establish cooperation relationship with all countries including its former enemies. This happened not because of a change of Chinese power, territory, population, or military strength. In 1960's, China carried out a foreign policy that confronted both the west countries led by the US and the bloc of the Soviet Union. Such policy is not based on the consideration of the 
balance of power, but on Chinese leaders' understanding of the world.

There are a lot of new ideas have been accepted by new Chinese leaders, and have become important guide of Chinese national strategy and foreign policy. The change of conception will influence both decision-making of Chinese foreign policy and Chinese definition of its role in the world.

\section{Chinese New Concept of Security: Beyond Realism}

One important conception related to Chinese foreign policy is the definition of the world situation. Chinese leaders like to say that peace and development remain the themes of our era. This reflects a Chinese definition of the current world, which is the starting point of Chinese policy. The report of recent Chinese $16^{\text {th }}$ Party Congress starts with this in the international situation part: "to preserve peace and promote development bears on the well-being of all nations and represents the common aspirations of all peoples. It is an irresistible trend of history. A new world war is unlikely in the foreseeable future. It is realistic to bring about a fairly long period of peace in the world and a favorable climate in areas around China." This means that the goal of Chinese foreign policy and defense policy is to create a peaceful and stable international environment for Chinese economical development and domestic reform, which is a continue of the essence of polices promoted by Deng Xiaoping and Jiang Zhemin since Chinese reform and open. Deng asked that China's foreign policy should serve for the axis of economic reform and constructions. Toward a purpose of creating some good international environment, particular some friend neighborhood, China did rethink of its relations with countries such Vietnam, India, South Korea, and what is more did readjust of its cooperation with Russia and some central Asian states.

This also means Chinese government will continue to see the development and stability as priorities of its national strategy, and doesn't define an immediate enemy in its strategy. Both Chinese leaders and scholars have recognized and admitted that after the Cold War, the role of military elements has been decreased in a manner that the arbitrate of disputes and conflicts by international organizations and other international institutions becomes influential increasingly, that economic and financial factors in contrary with traditional military ones have occupied prior position.

The new conception of security is another important new idea accepted and advocated by Chinese leaders recently. In China $16^{\text {th }}$ Party Congress report, this new concept has been highlighted with eight Chinese words: "mutual trust, mutual benefit, equality and coordination". Theses words do not appear very 
new, but China has put something new in them, which reflect new Chinese understanding of world security and international relations. China tends to believe that national interests or national security couldn't be achieved just by military power, and international cooperation is becoming an important way to realize national interests. China hopes to seek its national security through international cooperation. China holds that there are different ways to realized national security, and one country can realize its security without threatening other countries security. China calls it 'cooperative security', 'common security', or 'win-win security'. This means China is trying to establish a sort of cooperative relations or partnership with other countries, instead of alliance targeting on other country. China doesn't want to see its drive to national security and development be regarded as a threat to its neighbors or other countries.

In new document of the Party Congress, China defines its relationship with neighbors as relationship of friends and partners, trying to have a "friendly ties with the neighbors and persist in building a good-neighborly relationship and partnership with them". On the one hand, China will persuade other countries to understand its new security ideas, and on the other hand, China will put these ideas in practices. In recent years, China has discussed the issue of South Chinese Sea with ASEA countries, has resolved some boundary issues with Central Asia countries, has demarcated its boundary with Russia, and has reached an agreement of land boundary with Vietnam. These facts indicate that China is paying more and more attention to establish a good neighborly relationship. Chinese rapid economical development doesn't lead to demand of territories or regional expansion. In vice premier Qian Qichen's words, a prosperous China is not to snatch cake from other countries, but to make a bigger cake for them. ${ }^{4}$ Chins will try to play a more active role in surrounding regions, especially in Northeast Asia. In some cases, China may have more important influence than other powers in this region. But generally, Chinese policy to this region is prudent and cooperative one, both for the reason of building a good image and for the need of its real interests.

Some scholars argued China should play more important role in Asian affaires, and should not give up the leading role to the US. They thought Chinese foreign policy was too passive. But even scholars who held this views strongly recognized that "China should, together with other big powers, excise its leading role in the process of establishing political and economical mechanism in East

${ }^{4}$ Qian Qichen's speech at Peking University, International Politics, International Relations College, Peking University.2002.2.p6 
Asia." ${ }^{\circ}$ New Chinese leaders are inclined to stick to Deng Xiaoping's teaching "development is overwhelming priority", and they believe China can achieve its national interests and security through cooperation with other countries, not through military expansion or territory demands.

The other important concept of Chinese foreign policy is comprehensive security and non- traditional security. This is not a Chinese patent. After the end of cold war, these concepts have been put forward. Chinese government pays more attention to new global challenges, and believes international relations are not just limited to traditional power struggles or military conflicts. The concept of security has extended to a broader field, including economical security, information security, financial security, ecology security and social security.

We believe international relations are not always as the same as what realists describe. They are changing, evolving from lower level to higher level. Today, we can't say international community has got rid of the anarchy, but we have witnessed more cooperative mechanisms in global level and regional level. We would like to say that Chinese policy toward this region is based on the belief that cooperation is the best way to achieve its interests.

\section{Cultivate a Cooperative Political Culture in Asia}

Compared to Europe, what Northeast Asia lacks for regional cooperation are not economical requirements, but a kind of political culture of mutual understanding and mutual trust. After the Second World War, European countries began to cultivate its regional political identity. This process was pushed forward by European politicians with foresight. Asia, especially Northeast Asia, is still dominated by realism thinking and political culture of power seeking. Because of external invasions and internal conflicts, Asian political culture has never evolved to a sort of political culture beyond national boundary. European countries have developed form a political culture of "high rivalry relationship" to another kind political culture, namely a political culture of 'seeking common ground while reserving differences', which is the budding stage of "great harmony culture". The political culture conducting Asian international relations is still a sort of "Cold War thinking" or "high rivalry culture".

We must recognize that regionalism has not taken its shape in this region. Asian countries have neither theories of economic regionalism, nor theories of regional security cooperation. Most countries are paying more attention to

${ }^{5}$ See Ye Zhicheng, “China: Diverse Role of Choice”, Global Times, March 17, 2000. 
strengthen sovereign state and national unity, not to cultivate the regional integration or regional identity. For most Asian countries, strengthening sovereign state and national unity and are still priorities. Asian countries are at a stage that is quite different form European countries at.

Until Asian countries are confident in their national stability and state sovereignty, give up old thinking and begin to cultivate a political identity and cooperative culture beyond state boundary, regionalism will not grow up in this region.

These are very popular views in the circle of Chinese scholars. Profess Chen Jiru points out: high-level regional economical cooperation, such as establishment of a common market and issuance of a unified currency, is related to the sharing of sovereignty among member states in the cooperation. This requires a high degree of mutual trust. The success of European Economic Community is based on the reconciliation between France and Germany. The key to the France-Germany reconciliation is that Germany has taken a correct attitude toward the history of the World War Two. ${ }^{6}$

Some Chinese scholars hold that the economical need can push forward the regional cooperation. But more scholars believe that, in t Northeast Asia, the economical need hasn't yet been strong enough to make countries in this region go beyond the political limitation. Trade of ordinary goods is no problem, but it is another thing when the cooperation is related to what be called "strategic materials" or "strategic program "such petroleum exploitation, pipeline or railway construction.

We believe that economical need is very important factor of economical cooperation, but it is possible to establish a good cooperation between countries with positive political will given unfavorable economical precondition. There is an optimistic view on Northeast Asian cooperation, which is based on the need of "supplemental economy". According to this view: whose countries that have supplemental economical structure are easy to establish cooperative relations. They believe that Northeast Asian countries have good condition of regional cooperation: Chinese cheap labor, products, vast market; Japanese advanced technology, ample fund; Russian rich resources, high quality education. But this is not just an economical problem.

Professor Shen Jiru shares views with us, and he argues EU members are highly similar to each other like France, Germany, Belgium and Luxembourg. Though these countries have not supplemental economy structures, but they

${ }^{6}$ Shen Jiru, "China and Japan in East Asian Regional Economic Cooperation" International Understanding, Vol. 3, 2002, pp.36-37 
have established a common market. His conclusion is that the economical need or supplemental structure is not the key factors for success of regional economic cooperation, the decisive factors of successful regional economic cooperation lied in mutual trust, mutual benefit. ${ }^{\text {? }}$

The lack of political will and identity make Northeast Asian Countries face a dilemma between establishing further economical cooperation. Some Chinese scholars believe China has more important national interests in surrounding countries. But more and more Chinese people have begun to be impatient to "China threat", and argue that China should not pay more emphasis on economical cooperation with surrounding regions than on other countries. They don't think surrounding countries are more favorable places than other places such as France, Germany, Cuba, and Denmark and "instead we face more distrust, more military treaties against China, and more "China threat" in these regions." So their conclusion is: "WTO is more important than regional cooperation." "Chinese scholars quite agree "political factor" and "psychological factor "pose a great obstacle to the economical cooperation of Northeast Asian region. It is both a very hard work and a very necessary step for Northeast Asian Countries to overcome non-economical obstacles, and cultivate a cooperative culture for further regional cooperation.

\section{Establish a Regional Cooperation Framework with Northeast Asian Character}

In consideration of the diversity of this region, Northeast cooperation should be an inclusive one, and also should be establish on different levels.

When two countries are not in a war, confrontation and cooperation are the main categories of their relationship. Looking at the relations between related countries or actors in Northeast Asia, we can find they are involved quite complicated relations.

Regarding the relations between the two parts of Korea or two parts of China, the confrontation relations have not ended. The other bilateral relations may belong to cooperation relationship. This means they have a relationship with cooperative elements in dominant position. The international relations of Northeast Asia are different from other regions. In Northeast Asia, there exist many kinds of relations: relations between different political systems, relations between regional powers, relations between global powers, and relations

\footnotetext{
${ }^{7}$ Ibid.

${ }^{8}$ Shan Shi, "WTO More Important Than Regional Integration", Global Times, March 17, 2000
} 
between the West and the East countries. This is the most distinct character of Northeast Asian relations.

After World Wara!, the bipolar world shaped and the two blocs with different political systems began their confrontation nearly forty years. The most serious threat to the word was a nuclear war between the two blocs led by Soviet Union and the United States. After the end of Cold War, the first socialist country-Soviet Union and the East European socialist countries changed. Confrontation of systems in Europe ended. In global scope, this kind of confrontation is not the mainstream of international relations. But when we turn our eyes to Northeast Asian region, we may see the picture different from other regions. The system confrontation is still an aspect of this region.

We can't say the system confrontation is over in global scope, since there are still socialist states in the world. Most people believe that countries with the same political system would not confront each other. They can get along peacefully and they can solve their disputes by peaceful means, not by war. This is one of the important reasons why America and other countries are very easy to see China as a threat and try to change its political system.

In Northeast Asia, the system confrontation and national security issues always combine together. The Cold War was a mixture of power confrontation and political system confrontation. The system confrontation in Northeast Asia closely connects with major power's competition and also with the security interests of all countries and parts. The political system confrontation is not only a problem relevant to the existence of a system, but also relevant to the existence of a state.

In Northeast Asia, external issues and internal issues are so closely combined that you can't say Taiwan issue or Korean Peninsula issue is external issue or internal issue. The division or unification of Korea or China, and the way of dealing these issues, are always been regarded as vital factors in maintaining the balance of power in this region.

In different time, ideology has different impact on international relations and foreign policies. It is hard to say that the Cold War between Soviet Union and America caused by the conflict of different systems or by their different national security interests. Taking Sino-US relations for instance, in early 1970's, China and the US established formal diplomatic relationship and realized the normalization of their state relations. That happened when there was not a political system change within China. After the end of Cold War, China's opening and reform policies have achieved great progress. In many fields China has narrowed its ideological gap with the US. Even in American standing, China 
has made much progress in democracy, economic reform, human rights, arms control and other fields. But American government still believes China is a threat in the future. In Chinese scholar worlds: "even if China was a country with a political system according to American Constitution, the US still wouldn't like to see China become a superpower in the world. But scholars like to emphasize the ideological factor when they analyze Northeast Asia issue. American scholar Scalapino believed China wouldn't like to see the collapse of North Korea, one of the reasons is China "would like a Korea that is politically compatible, or at a minimum, does not present a challenge to its domestic political structure." 9

We don't think ideological differences remain the obstacle to regional cooperation. In Chinese side, it has given up to division the world by ideology. Chinese leaders like to stress that: "Our world is a colorful world. Countries having different civilizations and social systems and taking different roads to development should respect one another and draw upon one another's strong points through competition and comparison and should develop side by side by seeking common ground while shelving differences." 10

We also don't agree the clash of civilization will lead to regional conflict in Asia. According to Samuel P. Huntington's theory "the clash of civilizations", different religions and civilizations will be the cause of most conflicts. In Huntington's writes, he believes Chinese society and other non-Western countries may have a coalition against the Western countries. "Those countries that for reason of culture and power do not wish to, or cannot, join the West compete with the West by developing their own economic, military and political power. They do this by promoting their internal development and by cooperating with other non-Western countries. The most prominent form of this cooperation is the Confucian-Islamic connection that has emerged to challenge Western interests, values and power. ${ }^{11}$ There is no reason to support this argument.

In Northeast Asia, we do not think there is a fundamental confrontation of civilizations among Chinese, Japanese, Korean or other people, despite of the distrust and conflict of their cultures. We believe the East culture has a lot of links and similarities inside, and also open to the other cultures. If you see how greatly the West culture has influenced the life of Chinese people, you will believe the West civilization and the East civilization can coexist peacefully.

\footnotetext{
${ }^{9}$ Robert A. Scalapino: The Major Powers and the Korean Peninsula,

The Korean Journal of National Unification, Vol.3, 1994

${ }^{10}$ The 16th. Party Congress Report, People Press, Beijing, Nov. 2002, p.43

${ }^{11}$ Samuel. P. Huntington, "The Clash of Civilizations", Foreign Affairs, Summer 1993, v72, n3, p22 (28)
} 
Northeast Asia can be an example of the cooperation and coexistence of different political systems and civilizations.

What all states should do is to prevent the extremely nationalism from turning into mainstream of national policy. And what most important to this region is not economical factors, not different political systems or different cultures, but a mutual understanding culture and a mutual trust mechanism, which should be based on a common understanding of national security and other national interests.

As mentioned above, the system issue is not just an ideology problem, more important, it is a national security issue for all parts. A country facing too many pressures or with too many feelings of insecurity or unbalance will have no confidence in dealing with other countries or participating in multilateral cooperation. So to respect the existing political systems, and guarantee the security of all parts in this region are the first step toward a security mechanism and the development of a coexistence culture. Since there is not a dominant culture, religious or nation-state in this region, the new political identity or culture we advocate should be open and comprehensive without opposing against any cultures and without threatening any states. Then we can discuss problems like how to realize national unity, how to establish further economical cooperation or multilateral security mechanism in the future.

For this end, we need a transition of some fundamental conceptions. We are cooperation counterparts, not enemies. So if we hope to end the confrontation in action, we must end the confrontation in our mind first.

In Northeast Asia there should be different cooperation in different levels because of the complicated and diverse relations in this region.

The basic level involves the relations between North Korea and South Korea, and the relations between China mainland and Taiwan. We think it is the core of the regional security cooperation. If there are no cooperative and peaceful relations in this level, the mechanism of regional multilateral cooperation could not be established finally.

Cooperation among China, South Korea and Japan will be the driving force of future regional cooperation. Most Chinese scholars propose these three countries should take the lead in promoting regional economical cooperation because of their existing cooperative relations. Only when the three countries have a further cooperation and play an active role in regional cooperation of Northeast Asia, we can expect to build a regional cooperation including all parts of Northeast Asia.

The cooperation at the standard Northeast Asian level includes all 
geographically related countries and parts in this region, reflecting a regional cooperation in real meanings.

Then the level of North Pacific Region involves Northeast Asian countries and the United States, Canada and others. It is the cooperation in the broadest sense. The relations of this level are not only important to Northeast Asia, but also important to Asia and to the world.

Cooperation at different levels may influence each other and play different role on the process of regional cooperation. If the first circle relations could not be in good situation, it will be the main obstacle of regional cooperation. It is obvious if there is a conflict or crisis between Taiwan straits, we could not expect a stable relationship between China and the US. Chinese relations with Japan, South Korea, and other countries will face great challenges since these countries have a treaty with the US. The same will be the Korea issue. Without a stable and peaceful relations between two Koreas, there will be no real security cooperation in Peninsula and Northeast Asia. It is at this level that reflects the openness and inclusion of Northeast Asian cooperation. We all know Northeast Asia is a focus of world and regional powers, so the regional cooperation couldn't stable without a multiple regional cooperation including all related major countries. In such a big circle, there are many differences and conflicts, but every country may have more room to choose. Some Chinese scholars believe that it is easies to reduce the worries of "China threat" under a broader framework of cooperation in Asia. So cooperation at this level can play a role of guarantee and balance. ${ }^{12}$

Cooperation at different level has different function to realize regional security and development. Such cooperation may progress both synchronously and asynchronously. Northeast countries can play different role at different level of cooperation.

\section{What Should China Advocate in this Region?}

According to the basic ideas of Chinese foreign policy, China will and should play a more active role in this region. China is a very important regional power in Northeast Asia, and it can play crucial role on promoting regional economical development and regional security. But China is not a dominant power in this region, and it is restrained by other powers. China's policy toward this region should be prudent with an emphasis on status quo, stability and cooperation with other countries.

${ }^{12}$ Xiao Huanrong, Regionalism: A Historical Evolution of the Theories, Beijing Broadcast Institute Press, 2003, p.241 
China may pay more attention in building a comprehensive security regional mechanism, which will involves both traditional security issues and non-traditional issues such as boundary trade, finance management, labor export, transnational crime, illegal immigrants, and other non-traditional crime.

As an important power in this region, China should do its effort to promote the development of regional cooperation. In consideration of the lack of identity in this region, what we should do is overcome this shortcoming. Leaders of Asian countries, especially Chinese leaders, should have foresights when dealing with regional issues.

First of all, there is a need for creating a favorable political atmosphere for regional cooperation. China should begin to think about how to cultivate a common culture of Asia, which will be a kind of coagulate both in favor of regional solidarity and in favor of a open social structure against exclusionism. In consideration of the diversity of Asia, to respect the diversity of this region is important when we try to create an Asian political culture.

For this end, we need wisdom and courage of politicians to promote process of cooperation. Politicians, mass media, intellectuals, and especially elites of young generation should consciously prevent extreme nationalism and exclusionism from becoming mainstream views. Since there is not an old identity of culture, religious, or nationality, it is necessary to advocate a kind of new principles that could be accepted by all Asian countries. Such principles should not aim at eliminating the diversity of this region, and should be in favor of creating a political culture of non-antagonism.

In fact, there is no reason to support Samuel. P. Huntington's theory of "The Clash of Civilizations". It is more likely that China utilizes the peaceful character of its culture and independent international position (not a member of the western group, not a member of G 77) to promote the dialogue between different civilizations, instead of constructing an alliance against another civilizations. Chinese government has expressed its political will to be a more responsible country in maintaining world peace and security.

China should establish constructive relations with Asia countries, including existing alliance. China should hold dialogue with related countries that belong to different treaties and even participate in their activities. Russia's practice of establishing relations with NATO provides China with enlightenment.

At the same time, China opposes a hegemony power in this region. China doesn't hope to see a super-hegemony power in this region, which can dominate the whole regional security affaires. China opposes alliance that targets the 
third country, and opposes any attempt to forge a military chain surrounding China to threat Chinese security and development. China doesn't want to establish a traditional alliance with Russia, but want to have a close partnership or strategy relationship with other Northeast Asian countries, to deter the rising of a super hegemony in this region, and keep the balance and stability of this region. 